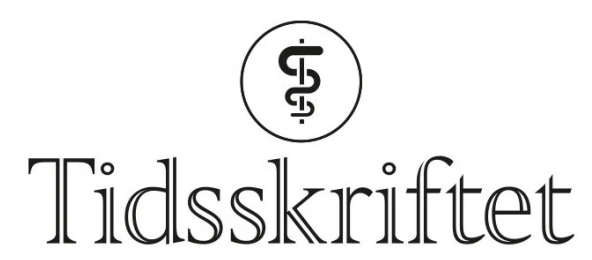

DEN NORSKE LEGEFORENING

\title{
Morten Harboe
}

\author{
MINNEORD
}

GUNNAR AKSEL BJUNE

TORE GODAL

\section{BJØRN MYRVANG}

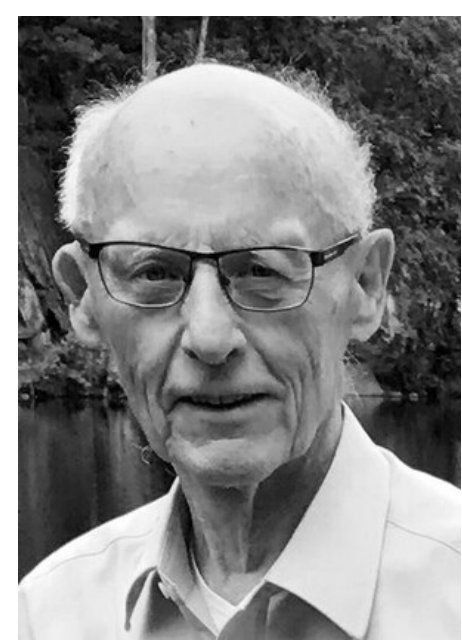

Professor Morten Harboe døde 1. april, nesten 92 år gammel. Han var landets første professor i immunologi, og han har fått mange godord og priser for innsatsen han la ned gjennom et langt liv. Vi vil hedre ham like mye fordi han var en pioner i etableringen av medisinsk forskning i Afrika. Da han påtok seg å lede Armauer Hansen Research Institute (AHRI) i Addis Ababa, var det starten på norsk forskningsengasjement i kampen mot infeksjoner som særlig rammer mennesker utenfor landets grenser.

Ideen om å etablere et forskningsinstitutt for lepra i Armauer Hansens navn kom fra universitetsmiljøet i Bergen. Men det var ikke penger å hente ved universiteter i Norge. Heldigvis fikk man Norad (Norge) og Sida (Sverige) til å bekoste bygging av et forskningslaboratorium ved leprasykehuset i Addis Ababa. Og Redd Barna i Norge og Rädda Barnen i Sverige påtok seg sammen å dekke driftsutgiftene fra starten og i en del år framover. Da landets fremste immunolog, Morten Harboe, sa seg villig til å lede forarbeidet og instituttet det første året, var saken i gode hender. Harboe var midt i en trygg forskningskarriere ved Universitetet i Oslo da han reiste til Etiopia i 1969. En indisk patolog og en yngre norsk lege ble hans viktigste medarbeidere. 
Instituttet ble innviet med stor stas i mars 1970. Keiser Haile Selassie foretok den høytidelige åpningen og ble vist omkring i laboratoriet. For keiseren og etiopiske myndigheter var det et stort øyeblikk da et institutt ble etablert for skandinaviske penger for forsking på den til delvis neglisjerte sykdommen lepra, som var et stort problem i landet. I tillegg til en beskjeden utenlandsk stab på fem, ble etiopiere, stort sett uten utdanning, ansatt i ulike stillinger.

Med små ressurser innledet Harboe et prosjekt som i ettertid må betegnes som meget vellykket. Instituttet ble i løpet av få år et internasjonalt kjent forskningsinstitutt for lepra med vitenskapelig produksjon på høyt nivå. Harboes ledertid var kort, men han forble engasjert i instituttets arbeid, blant annet i dets styre, i alle år framover, og han etablerte et viktig samarbeid med Universitetet i Oslo. Flere ganger reiste han til Etiopia for å trå til når instituttet hadde vanskeligheter.

Etter 50 år har AHRI vokst fra ca. 20 ansatte, som var konsentrert om lepraforskning og finansiert fra Norge og Sverige, til å bli det ledende biomedisinske forskningsinstituttet i Etiopia, med 350 ansatte, eid av Helseministeriet, ansvarlig for oppbygging av bioteknologi, klinisk utprøvning av medikamenter, utdanning av biologiske forskere til de ca. 30 universitetene i landet og - $\mathrm{i} \emptyset$ yeblikket en hjørnestein i landets arbeid med koronapandemien. Selv om Norge og Sverige fortsatt bidrar, og har gjort det gjennom all slags politisk uvær, kommer driftsmidlene nå først og fremst fra instituttets evne til å vinne internasjonale forskningsmidler. Og den etiopiske regjeringen satser på omfattende utbygging av lokaler og kapasitet.

At Morten Harboe sa seg villig til være leder i instituttets startfase, og siden engasjerte seg sterkt $i$ at instituttet skulle leve videre og bli en vitenskapelig hjørnestein i Etiopia og Afrika, minnes og takker vi, og mange andre, ham for.

Publisert: 25. mai 2021. Tidsskr Nor Legeforen. DOI:10.4045/tidsskr.21.0300

(C) Tidsskrift for Den norske legeforening 2023. Lastet ned fra tidsskriftet.no 26. april 2023. 